\title{
Nurses' perception on violence against children and adolescents by their companion in pediatric ward
}

\author{
Percepções do enfermeiro sobre violência contra criança e adolescente praticada pelo \\ acompanhante na enfermaria pediátrica \\ Percepciones de las enfermeras sobre la violencia contra los niños y adolescentes ejercida por \\ el acompañante dentro del sector pediátrico
}

Lindsay Ibacache Barrenechea' ORCID: 0000-0003-3843-6080

Camila Camacho Ribeiro' ORCID: 0000-0001-7950-1681

Angela Maria La Cava' ORCID: 0000-0003-4173-8557

Otilia Pimenta Azevedo" ORCID: 0000-0003-0299-710X

'Universidade Federal do Estado do Rio de Janeiro. Rio de Janeiro, Rio de Janeiro, Brazil. "Estado do Rio de Janeiro, Secretaria de Estado de Saúde. Rio de Janeiro, Rio de Janeiro, Brazil.

How to cite this article: Barrenechea LI, Ribeiro CC, La Cava AM, Azevedo OP. Nurses' perception on violence against children and adolescents by their companion in pediatric Ward.

Rev Bras Enferm. 2020;73(Suppl 4):e20190495. doi: http://dx.doi.org/10.1590/0034-7167-2019-0495

Corresponding author: Lindsay Ibacache Barrenechea E-mail: lindsaybaib@gmail.com

EDITOR IN CHIEF: Antonio José de Almeida Filho ASSOCIATE EDITOR: Ana Fátima Fernandes

Submission: 03-12-2020

Approval: 06-10-2020

\begin{abstract}
Objectives: to know the nurses' perception on violence against children by their companion in pediatric ward; describe the nurses' actions in this situation; analyze these actions in light of government policies; and know the organization and communication of the multidisciplinary team to face this phenomenon. Method: a descriptive qualitative research conducted through semi-structured interviews with nurses. Thematic analysis identified three categories:"A perception of violence"; "Actions and interventions performed by nurses"; and "Multidisciplinary team organization and communication". Results: nurses recognize the types of violence, but attaches greater severity to physical violence. The reported causes were children with difficult temperaments, transgenerational violence and hospitalization. The actions were dialogue, companion-child separation, registry and notification to the Guardianship Council. Poor communication from the multidisciplinary team and medicalcentric organization have been reported. Final considerations: public policies are directed towards violence outside institutional environments, consequently they lack guidelines for addressing witnessed situations.

Descriptors: Nurses; Violence; Child; Hospitalization; Caregivers.
\end{abstract}

\section{RESUMO}

Objetivos: conhecer a percepção dos enfermeiros sobre a violência contra a criança praticada pelo acompanhante na enfermaria pediátrica; descrever as ações do enfermeiro nesta situação; analisar essas ações à luz das políticas governamentais; e conhecer a organização e comunicação da equipe multidisciplinar no enfrentamento deste fenômeno. Método: pesquisa qualitativa descritiva, realizada mediante entrevista semiestruturada com enfermeiros. A análise temática identificou três categorias:"A percepção da violência"; "Ações e intervenções realizadas pelo enfermeiro"; e "Organização e Comunicação da equipe multidisciplinar". Resultados: o enfermeiro reconhece os tipos de violência, porém atribui maior gravidade à violência física. As causas relatadas foram: crianças com temperamentos difíceis, violência transgeracional e hospitalização. As ações foram: diálogo, separação acompanhante-criança, registro e notificação ao Conselho Tutelar. Foi relatada comunicação deficiente da equipe multiprofissional e organização medicalocêntrica. Considerações finais: as políticas públicas estão direcionadas à violência fora dos ambientes institucionais, consequentemente, carecem de diretrizes para abordagem de situações presenciadas.

Descritores: Enfermeiros; Violência; Criança; Hospitalização; Cuidadores.

\section{RESUMEN}

Objetivos: conocer la percepción de las enfermeras sobre la violencia contra los niños y adolescentes ejercida por el acompañante dentro del sector pediátrico; describir las acciones de la enfermera en esta situación; analizar estas acciones a la luz de las políticas gubernamentales; y conocer la organización y comunicación del equipo multidisciplinario para enfrentar este fenómeno. Método: investigación descriptiva cualitativa, realizada mediante entrevista semiestructurada con enfermeras. El análisis temático identificó tres categorías: "La percepción de la violencia"; "Acciones e intervenciones realizadas por la enfermera"; “ "Organización y comunicación del equipo multidisciplinario". Resultados: la enfermera reconoce los tipos de violencia, pero atribuye mayor severidad a la violencia física. Las causas informadas fueron: niños con temperamentos difíciles, violencia transgeneracional y hospitalización. Las acciones fueron: diálogo, separación de niños y compañeros, registro y notificación al Consejo Guardián. Se informó una comunicación deficiente por parte del equipo multiprofesional y la organización medicalocéntrica. Consideraciones finales: las políticas públicas están dirigidas hacia la violencia fuera de los entornos institucionales, por lo tanto, carecen de pautas para abordar situaciones presenciadas.

Descriptores: Enfermeros; Violencia; Niño; Hospitalización; Cuidadores. 


\section{INTRODUCTION}

Violence against children and adolescents has become a major public health problem, drawing the attention of heads of state and health professionals worldwide ${ }^{(1)}$. However, conceptualizing violence has been a challenge, since the "regenerating action or feeling related to violence can have multiple and different meanings depending on the culture, moment and conditions in which they occur"(2). Thus, in 2002, the World Health Organization (WHO) defined violence as:

The intentional use of physical force or power, threatened or actual, against oneself, another person, or against a group or community, that either results in or has a high likelihood of resulting in injury, death, psychological harm, maldevelopment, or deprivation ${ }^{(3)}$.

To consolidate and defend the rights of children and adolescents, the Child and Adolescent Statue (Estatuto da Criança e do Adolescente, abbreviated ECA) was introduced. It was emphasized that "it is the duty of the family, the community, society in general and the public authorities to provide all the opportunities and facilities for full physical, mental, moral, spiritual, and social development" (freely translated into English from the original version in Portuguese) ${ }^{(4)}$.

Despite all the legislative advances, violence against children and adolescents is a problem that still prevails. It is permeated by silence and by the concept that corporal punishment and humiliation are educational resources, justified as a way to educate and correct behavioral transgressions ${ }^{(5-6)}$. This is the reason why aggressors are often relatives of victims.

The disease and the hospital environment can cause imbalance in children and their families ${ }^{(7)}$, who may not be emotionally prepared to face these conflicts. Parents, for not having positive coping methods, can use violence as a means to reestablish family dynamics ${ }^{(8)}$.

Nursing has a privileged position among the other professionals of the multidisciplinary team, since it is in direct contact, being able to recognize the signs of violence more easily ${ }^{(9)}$.

This research is justified by the need to explore the actions and interventions performed by nurses in the face of violence against children by their companion in pediatric ward; considering that nurses struggle with positioning themselves when they witness violence against children. The approach of this research aims to contribute to health work planning, in order to influence service organization by creating specific care flows to face violence against children and adolescents.

\section{OBJECTIVES}

To know the nurses' perception about violence against children by their companion in pediatric ward; describe the nurses' actions in situations of violence against children by their companion in pediatric ward; analyze the nurses' actions to face violence against children by their companion in pediatric ward, in light of government policies; and get to know the organization and communication of the multidisciplinary team to face the violence against children by their companion in pediatric ward.

\section{METHODS}

\section{Ethical aspects}

This study was submitted to an ethical analysis and approved by the Research Ethics Committees of Universidade Federal do Estado do Rio de Janeiro and the federal hospital where data collection took place. The standards established by Resolution 466/2012 and by Operational Standard 001/2013, both of the Brazilian National Health Council (Conselho Nacional de Saúde), which regulates research involving human beings, were complied with.

All participants signed the Informed Consent Form (ICF), in which confidentiality and anonymity were ensured through the use of letter $\mathrm{N}$ (Nurse) and the number corresponding to the order of participants.

\section{Type of study}

This is a descriptive qualitative research. The descriptive research "aims to identify, record and analyze the characteristics, factors or variables that relate to the phenomenon or process"(10).

\section{Methodological procedures}

\section{Study setting}

The study was carried out in the pediatric ward of a large federal hospital, located in the city of Rio de Janeiro, with 31 beds.

\section{Data source}

We chose the research participants intentionally, considering the totality of 14 nurses who work regularly at pediatric ward; however, due to vacation and sick leave during the data collection period, it was only possible to interview 10 nurses on duty.

\section{Collection and organization of data}

Data collection was carried out in April 2019, through a semistructured interview, carried out individually by the researchers in a private room. The interviews lasted an average of 10 minutes; were recorded on audio; transcribed in full; and were composed of the following questions: how long have you been working as a nurse in a pediatric ward? Have you ever witnessed any situation of violence against children by their companion in the hospital? Which one? What actions did you take or would you take when you witnessed violence against children in the hospital?

\section{Analysis of data}

Data analysis was carried out through thematic analysis, described by Bardin, which "consists of discovering the core meanings that compose communication and whose presence or frequency can mean something for the chosen analytical objective"(11). This analysis made it possible to identify three categories:"A perception of violence"; "Actions and interventions performed by nurses"; and "Multidisciplinary team organization and communication". 


\section{RESULTS}

All professionals were female, with a minimum of 6 and a maximum of 22 years of work in the pediatric ward, with an average of 13 years of experience in pediatric wards.

\section{A perception of violence}

When asked about having witnessed some type of violence from the companion against children in the hospital environment, eight nurses reported that "yes" and two that "they had never witnessed".

To speak of violence, nurses had to classify it by its nature, being separated, naturally, as physical, psychological and abandonment/ neglect:

Physical aggressions and verbal, psychological aggressions, psychological violence and abandonment. These were the violence that I saw, that I saw the companions perform with children. (N3)

Any violence, violence, do you mean physical? Or psychological? What kind of violence? (N5)

These statements allow us to infer that nurses have the perception that violence is not restricted only to physical and visible aspects, demonstrating an advance in the understanding of the phenomenon of violence. However, even considering the existence of other forms of violence, some professionals seemed to place a greater emphasis on physical than psychological violence:

Nothing severe. Only verbal aggression. Mother fighting, but nothing to hit or hurt the child, no. (N2)

The mother threatens the child, if he does that, it will happen to him, that kind of threat. But, something serious, something that really hurt, it's okay that it hurts, right? Mostly psychological, it hurts too much. But, physical violence, anything that hurt, I have never witnessed. (N5)

Physical violence appears in the speeches, associated with the severity and force employed in it, giving the concept of not being serious, for being "just a slap", compared to beating. Physical violence is normalized and naturalized as a socially accepted means of education. Thus, correcting a child using physical aggression would not be wrong as long as in a moderate way. It is important to note that the concept of moderation is not unique and is open to different interpretations:

[...] physical, just slapping, no beating, leaving the child with a bruise, injured. That I have never seen. (N5)

Slap, right? 'Don't go, don't put your hand there, get out of there'. Slap, normal, but is not a beating. (N5)

Half of the nurses interviewed reported having witnessed some type of psychological violence, which is indicative of knowledge about the theme, managing to perceive this type of violence that is presented in a subtle way. Psychological violence was approached with special emphasis on the threat as a means of coercing the child and, thus, inhibiting behaviors considered wrong, in order to educate.

Usually, it is a threat to children, that if they do that, they will lose something or they will be beaten or they will no longer have what they like most, understand? It's always that kind of psychological threat to children. (N5)

Psychological abuse all the time threatens, right? 'Don't do this, otherwise that will happen to you, I will call your father.' Then there are the stories that so-and-so will get you, these things, psychological threat, causing children to be inhibited and not do what they were doing. (N5)

Concerning neglect and abandonment, one of the nurses' doubts about the inclusion of this type in the context of violence draws attention:

I don't know if abandonment counts [...]. I don't know if abandonment counts in the context of violence. (N10)

The most reported negligence was related to the companions being absent for long periods of time or not protecting children from any health problem:

I see many situations of neglect, the mother who interns the child and leaves her alone for days or many hours, with the excuse that she has other children. (N4)

[...] for instance, we have a patient here for a long stay that the mother does not put oxygen on, leaves the child out of bed at risk of falling, she is absent for a long time. (N10)

Respondents sought to understand violence in order to give it meaning. In search of causes to justify the phenomenon, they built their explanations on three different dimensions: children, parents and situation/environment.

When focused on children, their attitudes were mentioned as triggers of violence:

Usually, the child is making a fuss, something that the mother does not want her to do, and she does it because the child is like that, right? For the child to stop, the mother makes some kind of threat. (N5)

The mother beats the child to be quiet, to do a procedure. (N10)

When centered on parents, nurses build their hypotheses based on the education they had, considering that they reproduce with their children what they have learned from their parents. In other words, they tend to educate them in the same way they were educated:

[...] from my point of view, they do not do it because they want to, they do it because they are not oriented, they do not know at what level of violence, what is violence. So, whoever was created like this ends up transmitting it to theirs like that, so educating them is to attack. (N3)

[...] because they also love, they love their children, but the education they had is a. (N3) 
Quando centrados na situação/ambiente, os enfermeiros destacaram duas situações diferentes para tipos de violências distintas, relacionaram a violência física e psicológica ao estresse provocado pela internação hospitalar e o abandono às situações familiares:

Sometimes, mothers, just because they are the only ones who stay with the child all the time and are very nervous and anxious about diagnosis, as they cannot see other children or because of the difficult hospital situation, without having the support of the family, they enter in crisis. (N9)

Abandonment, when we go to see the context of this family, this family has several children, so it is not a matter of abandonment because it wants to abandon, very few abandoned it. This was for the Guardianship Council, but the rest leaves because it also has other family issues, involved in this family context, in this family institution. (N3)

\section{Actions and interventions performed by nurses}

Nurses reported several actions and interventions in the face of violence by the companion in the hospital. However, the responses were divergent, showing that they do not know or do not have a protocol on how to proceed in this situation:

No, [I don't know the protocols] because it never happened to me like that. (N1)

I believe that there must be some way that they follow [the boss], that if it happens, they will trigger someone, but I, particularly, do not know (N1)

Nurses reported that when they witnessed a situation of violence, they initially talked to the companions, with the aim of stopping the violence and guiding them on non-violent educational practices:

[...] you will talk to the father and mother, you will not just turn your back on them [...], you talk and you try, and at that moment, that has to end. (N1)

[...] but explaining to her that it was an aggression and inside the hospital, in a public institution, this could not happen again. (N3)

[...] we intervene saying that this is not how the child will stop, understand? Maybe she even wants to do it, right [...] but all with a dialogue with the mother and the child. (N5)

One of the nurses interviewed explained how to approach the companions, emphasizing the role of nurses as educators and emphasizing that the health professional should welcome the family and not judge:

[...] talking to the guardian is a simple thing when you can empathize with that family. So, you make an exchange with them, [...] it is a role for you to put yourself in the other's shoes and sensitize him or her [...] we need to be, at that moment, an educator. (N3)

[...] assess this family and not judge, because health professionals like to judge and that is not our role, our role is to support, protect, judge it is not our role. (N3)
Particular importance was given to the recording of violence witnessed in the order and occurrences book and in the medical record, considering it a way to guarantee care:

\section{[...] we record in the order and occurrence book (N6).}

I usually write on the record as many times as I see. 'I saw the mother beating, I saw the mother neglecting'. [...] and the way I have to guarantee the service is by writing. (N10)

Another action reported by the interviewees was the momentary companion-child separation as a measure to stop violence:

[...] we had to take more serious positions, to separate her child at that moment, then she came back. (N3)

If we witness, we have to separate this family at this moment of aggression, take this family, whoever is guardian of this child, so we can talk. (N3)

The importance of notifying the Guardianship Council was also reported. It was evidenced that professionals understand their legal responsibility to comply with the Compulsory Notification. However, they did not mention having informed the family that they would make this notification, nor that the notification was carried out in three ways: the first to the Health/Epidemiological Surveillance service of the Municipal Health Department; the second for the Guardianship Council and/or competent authorities (Juvenile Court or Public Prosecutor); and the third for the Health Unit that reported the case of violence:

[...] violence is violence, whatever it is, you have to communicate the Guardianship Council, because this is the law, this is a policy and the policy was made by a standard for us to comply with [...] any professional who witnesses any violence, whether physical, psychological, or other, must make a written complaint to the Guardianship Council. (N3)

Interactions with other team members were highlighted in order to better resolve the situation of violence, with physicians and social workers being cited mainly. Psychologists were also contemplated, who were assigned the role of assessing parents:

[...] we can try to talk to the medical team and the social service too. (N7)

I asked for support from social work, and there were times when I asked for mental health support for the mother, psychology. (N9)

Talk to the multidisciplinary team, the social service, the psychologist, ask for a better look at the situation. (N10)

\section{Multidisciplinary team organization and communication}

Nurses struggled with addressing cases of violence, due to the lack of communication between the different categories of the multidisciplinary team, highlighting the importance of such an approach in these cases:

[...] you have to be very careful when approaching mothers, precisely because there is no conversation with everyone on the 
team, so it may be that I say one thing, the physician says another, the social worker another, so it is very difficult for us to reach this point talk to them. (N4)

[...] boss, the physicians, I think that the whole team has to decide what they are going to do; I think it is not something that belongs to the nurse or that belongs to the physician or that belongs to the social service. (N1)

The physician-centered care organization was criticized, reporting that this organization impaired the interaction of nursing with other professional categories:

[...] everything here revolves around the physician, so we talk to the medical team and it is the medical team who takes the steps along with social work. [...] the physician meets with the parents to talk, the medical team itself and even the social service also enters, but never together with nursing. (N4)

Now, what I feel very difficult here is that we do not have direct access to a social service, [...] what we can be doing here is to signal to a physician, to signal to our boss, to pass from one on call for the other the situation. (N6)

In the same way that nurses reported having difficulties in communicating the situation with the multidisciplinary team, they reported not having a return on the measures adopted by the rest of the team; except when restrictive measures were implemented for any of the companions. Thus, interventions and referrals are not implemented in an integrated manner by the entire team:

In some cases, they return the information saying if a relative is forbidden to visit, [...] when there is a monitoring restriction, they pass it on to us. Other than that, we learn through the companion or the mothers who are accompanying other children. (N4)

\section{DISCUSSION}

In this research, all participants were female, an occurrence that can be explained by nursing being a predominantly female profession, since historically and culturally the act of caring was attributed to women and associated with an assumed "feminine essence $^{\prime \prime(12)}$. Association between care and the female gender is partly due to the fact that, historically, women have performed these activities at home, such as caring for children, the sick and the elderly ${ }^{(12)}$.

The perception of a phenomenon is closely linked to experiences, because it is based on them that the brain interprets and attributes meaning to events and situations ${ }^{(13)}$. Thus, the same event can be interpreted as violent or not, depending on the professionals' perception, since their interpretation of the situation will not be neutral, but will be marked by the personal experiences they had and carry with them. However, as perception is a construction of meanings, it is dynamic and can be modified by new experiences ${ }^{(13)}$.

The need to classify violence, present in the interviewees 'statements, may impair the professionals' perception of concomitant violence. They do not consider the possibility of the same child suffering different types of violence; fact evidenced in a study in Londrina, which revealed that $72.5 \%$ of the notifications in 2006 had a concomitance of violence ${ }^{(14)}$.

In agreement with the findings of this research, a study in Rio de Janeiro found that health professionals divide violence by its graduation and typology into explicit (mistreatment inflicted on the body that is visible) and subtle (including the non-visible, the injuries to the psychic development and citizenship) ${ }^{(15)}$.

The doubt presented in the interviewees' statements as to whether negligence is a type of violence or not is due to the fact that it is a subtle and barely visible violence; and, also, in the historical construction of the concept, which was initially considered as a modality within psychological violence, and not as a type of violence ${ }^{(16)}$.

Violence was related to the parents' need to control unacceptable behavior; a corrective educational strategy was considered, since the delimitation between education and violence is blurred due to ingrained historical and cultural factors, which consider children as beings in formation and property of their parents; and they, in turn, have a duty to direct them, being able to punish them, when necessary, as a method so that an inappropriate practice does not repeat itself ${ }^{(5)}$. This type of relationship between parents and children expressed by nurses is classified as authoritarian parenting. Such relationship aims at control and obedience through authoritarian parents, who strictly and arbitrarily punish their children when they do not fit the established standard ${ }^{(17)}$.

It is important to emphasize that, in the process of educating, it is necessary to impose limits. According to the Line of Care for Comprehensive Health Care for Children, Adolescents and their Families in Situations of Violence (Linha de Cuidado para a Atenção Integral à Saúde de Crianças, Adolescentes e suas Famílias em Situação de Violências), it must be carried out through dialogue ${ }^{(3)}$.

In accordance with the line of care, the Child and Adolescent Statute in Article 18-A stipulates:

Children and adolescents have the right to be educated and cared for without the use of physical punishment or cruel or degrading treatment, as forms of correction, discipline, education or any other pretext, by parents, extended family members, those responsible, by public agents executing socio-educational measures or by any person charged with caring for, treating, educating or protecting them ${ }^{(4)}$. (freely translated into English from the original version in Portuguese)

The nurses' hypothesis that parents are violent towards their children, due to the fact that they reproduce the educational standards to which they were submitted, is based on the transactional model of violence. Individual factors of parents (history of abuse) and cultural factors (cultural approval of violence use) are also considered as risk factors for the phenomenon ${ }^{(18)}$. The reproduction of violent parenting is a phenomenon called transgenerational violence. Children who are victims become aggressors as they tend to repeat patterns of behavior and family functioning experienced in childhood, from which inherit value models based on violence ${ }^{(8,19)}$.

These families need therapeutic work that allows them to restructure themselves, creating new coping dynamics for conflict situations, since they are unaware of non-violent methods. It is 
in this context that it is necessary to recover the abuser's psychic integrity, being the responsibility of society, which was not able to protect him or her as a child(8).

The individual factors of children expressed in interviewees'statements have also been widely discussed in international literature as a risk factor in the transactional model of violence. They were considered characteristics of children as "physical or psychological problems, hyperactivity, difficult temperament, passivity and frequent and severe illnesses"(18). It is important to emphasize that the search for these risk factors does not aim to blame the child for violence, but to determine which children are most vulnerable to violence, allowing a better targeting of public policies.

Some statements refer that the child's illness and the hospital environment may be factors that trigger violence. Such factors produce in mothers frustration associated with fear and uncertainty of the child's total health recovery, which generates a profound emotional overload and psychological distress ${ }^{(7)}$. In families that do not have a good support network, mothers, who tend to be the ones who remain most in hospital, may conflict with the reality of hospitalization. At the same time that they want to dedicate themselves to the sick child, they feel divided between the care for the children who stayed at home and the hospitalized, demanding that they play similar roles in different geographical locations ${ }^{(7)}$. According to the transactional model, low tolerance to frustration and stress by parents is a risk factor for violence ${ }^{(18)}$. On the other hand, some families show resilience, managing to overcome adversities and deal positively with hospitalization.

Therefore, welcoming this family by the multidisciplinary team is a preventive measure for situations of violence. The Brazilian National Humanization Policy (Política Nacional de Humanização) understands welcoming as an attitude of inclusion through acceptance, credibility, and approximation ${ }^{(3)}$. The Line of Care for Comprehensive Health Care for Children, Adolescents and their Families in Situations of Violence considers it essential to avoid judgments and accusations. And it explains that during the interview "it is essential to establish an empathic relationship, making it clear that the main objective is the protection of children or adolescents"(3).

The divergence in the actions and interventions performed by nurses shows the lack of a protocol for assistance in cases of violence against children and adolescents. But the Line of Care for Comprehensive Health Care for Children, Adolescents and their Families in Situations of Violence emphasizes that health services need to develop specific care protocols aimed at violence. Regardless of the reason that brought children or adolescents to the health service, health services need to investigate possible situations of family conflicts that generate violence among their members $^{(3)}$.

Health professionals must detect risks and victims as well as interact with parents, supporting them psychologically and helping them to develop relational, parental and social skills to face vulnerable and conflicting situations, in order to avoid violent $\operatorname{acts}^{(5,7,20)}$.

The Child and Adolescent Statue in Article 13 states that:

Cases of suspicion or confirmation of physical punishment, cruel or degrading treatment and mistreatment of children or adolescents must be reported to the Guardianship Council of the respective location, without prejudice to other legal measures $^{(4)}$. (freely translated into English from the original version in Portuguese)

In the Brazilian Code of Ethics for Nurses, it is stated that "nursing professionals respect life, dignity and human rights, in all its dimensions"(21) and that it is prohibited to "provoke, cooperate, be conniving or omitted with any form of violence" (freely translated into English from the original version in Portuguese) $)^{(21)}$.

Respondents understand that registering situations of violence is an obligation of nursing professionals, but doubts about the place of registry are frequent. Related to this, the Line of Care for Comprehensive Health Care for Children, Adolescents and their Families in Situations of Violence determines that the place to record the data related to care is the patients' medical records. Medical records should be as complete as possible as they can be requested in legal proceedings aimed at protecting children and adolescents. There is an indication that medical records should contain the procedures adopted, the measures taken and the referrals $s^{(3)}$.

Separation between parents and children emerged as a possible action in the face of violence; however, even in situations of in-hospital violence, the need to separate parents from their children should be thoroughly assessed, since their presence in the hospital benefits both. For children, it minimizes the psychological and emotional trauma of hospitalization; for parents, brings positive feelings related to participating constructively in their children's recovery ${ }^{(7)}$. No studies were found assessing maternal hospital deprivation in case of violence.

Considering the complexity of violence, the work of a multidisciplinary team is essential, as it can combine different knowledge, views and strategies. The Line of Care for Comprehensive Health Care for Children, Adolescents and their Families in Situations of Violence considers professional participation in mental health to be fundamental since the beginning of service ${ }^{(3)}$.

The existence of a multidisciplinary team does not guarantee comprehensive assistance for children victims of violence, as indicated by the interviewees. Therefore, it is necessary to articulate the different professional categories through effective communication among them ${ }^{(22)}$. However, several factors can impair communication such as the diversity in professional training, the tendency of one professional category to communicate more or less with another category and the effect of the usually physician-centered hierarchy. Hierarchical rigidity hinders the creation of a communication channel, making the categories act in parallel and not in an integrated and articulated way ${ }^{(22)}$.

Both the communication difficulties among the multidisciplinary team, reported by nurses, and the organization of assistance criticized by them are mainly due to the lack of protocols in the service for caring for children and adolescents who are victims of violence. This fact was also highlighted in a survey in the city of Cascavel, state of Paraná. The authors identified a need for the service to create protocols that define the steps and duties of each professional in the multidisciplinary team ${ }^{(23)}$. They considered that the creation of this protocol would avoid fragmented action, allowing a wide and quality assistance ${ }^{(23)}$. 
Likewise, in a participatory survey conducted in Paraná, health professionals highlighted the lack of communication between all multidisciplinary team members as one of the reasons for inefficiency of actions to deal with violence against children and adolescents; and identified the need to build a protocol that assists them in attending; however, they stressed that it would only work if it was elaborated by them because they know the institution's routine and problems ${ }^{(24)}$.

\section{Study limitations}

The main limitation of this study is related to the scarcity of reference for comparison, as there are no studies with an in-hospital approach to violence against children. Another limitation is due to the fact that it cannot be generalized, as it portrays a specific reality of a single hospital.

\section{Contributions to nursing}

It is believed that the results of this research can contribute for nurses to develop strategies for coping with in-hospital violence thus subsidizing actions to prevent recurrence. It is also considered that the research findings may contribute to health work planning, in order to influence service organization through the creation of specific care flows to face violence against children and adolescents.

\section{FINAL CONSIDERATIONS}

This study met the proposed objectives, showing an advance on the conception of violence from the nurses' perspective, not restricting it only to physical violence, considering the importance of psychological violence and neglect as aggressions that cause harm to children and adolescents. Still, the idea that violence is a socially accepted educational corrective strategy prevails in nurses.

Nurses' understanding of violence as a complex and multi-causal phenomenon was also found, with intergenerational cultural factors marked by education through violence. Possible causes of violence have been reported such as children with bad temperament; reproducibility on the part of parents of violence experienced in childhood; and hospitalization as a stress situation triggering violence.

The main actions performed by nurses were dialogue with the companion, companion-child separation, registry and notification to the Guardianship Council. But nurses performed different interventions. There was no standardization of actions, showing that even with the advances in nurses' perception of violence, coping with violence is still a challenge. Health professional training and creating institutional protocols are necessary to determine the actions to be implemented respecting an individualized and family-centered care plan.

The study showed that communication and articulation between the multidisciplinary team continue to be conflicting, maintaining a medical-centered organization. Despite this, nurses understand the need to improve communication and participation of the teams involved as a strategy to improve the quality of care.

Public policies for coping with violence are centered on the occurrence of events outside institutional settings and, therefore, professionals do not have defined guidelines on how to approach the situation of witnessed violence. It is recommended to carry out further studies addressing the theme and the adequacy of public policies to tackle violence within institutional environments, creating health care flows, thus equipping health professionals. The need to inspect the existence of internal protocols in health units is also highlighted, as established by the Line of Care for Comprehensive Health Care for Children, Adolescents and their Families in Situations of Violence.

\section{REFERENCES}

1. Ministério da Saúde (BR). Secretaria de Vigilância em Saúde. Departamento de Vigilância de Doenças e Agravos Não Transmissíveis e Promoção da Saúde. Viva: instrutivo notificação de violência interpessoal e autoprovocada. 2a ed. Brasilia:MS; 2016.92 p.

2. Almeida MGB. A violência na sociedade contemporânea. Porto Alegre: EDIPUCRS; 2010.161 p.

3. Ministério da Saúde (BR). Secretaria de Atenção à Saúde, Departamento de Ações Programáticas Estratégicas. Linha de cuidado para a atenção integral à saúde de crianças, adolescentes e suas famílias em situação de violências: orientação para gestores e profissionais de saúde. Brasília: MS; 2010 . 104 p.

4. Ministério da Saúde (BR). Estatuto da criança e do adolescente. 12a ed. Brasília: MS; 2014.241 p.

5. Bittar DB, Nakano AMS, Silva MAI, Roque EMST. Violência intrafamiliar contra crianças e adolescentes na percepção de mães agressoras. Rev Eletron Enferm. 2012;14(4):771-8. doi: 10.5216/ree.v14i4.15739

6. Ministério dos Direitos Humanos (BR). Secretaria Nacional de Proteção dos Direitos da Criança e Adolescente. Violência contra Crianças e Adolescentes: Análise de Cenários e Propostas de Políticas Públicas. Brasília: Ministério dos Direitos Humanos; 2018. 377 p.

7. Bezerra LFR, Fraga MNO. Acompanhar um filho hospitalizado: compreendendo a vivência da mãe. Rev. Bras. Enferm. 1996;49(4): 611-24. doi: 10.1590/S0034-71671996000400011

8. Seixas MRD. A violência transgeracional no caso Raul: exemplo de competente trabalho terapêutico em rede. Rev Bras Psicoter [Internet]. 2010 [cited 2019 Jun 24];12(2-3):225-37. Available from: http://rbp.celg.org.br/detalhe_artigo.asp?id=33

9. Valera IMA, Almeida EC, Baldissera VDA, Jaques AE, Bueno SMV. Nursing team practices in dealing with children and youth violence. Rev Bras Pesqui Saúde. 2015;17(3):103-11. doi: 10.21722/rbps.v17i3.14142

10. Nunes GC, Nascimento MCD, Alencar MAC. Pesquisa científica: conceitos básicos. ID on line. 2016;10(29):144-51. doi: 10.14295/idonline. v10i1.390 
11. Bardin L. Análise de conteúdo. Lisboa: Edições70; 2004. 225 p.

12. Lombardi MR, Campos VP. A Enfermagem no Brasil e os contornos de gênero, raça/cor e classe social na formação do campo profissional. Rev ABET. 2018;17(1):28-46. doi: 10.22478/ufpb.1676-4439.2018v17n1.41162

13. Pimentel I. Noções de psicologia aplicadas à educação. São Paulo: Melhoramentos; 1978. 232 p.

14. Martins CBG, Jorge MHPM. A violência contra crianças e adolescentes: características epidemiológicas dos casos notificados aos Conselhos Tutelares e programas de atendimento em município do Sul do Brasil, 2002 e 2006. Epidemiol Serv Saúde. 2009;18(4):315-34. doi: 10.5123/ S1679-49742009000400002

15. Braz M, Cardoso MHCA. Em contato com a violência: os profissiona.is de saúde e seus pacientes vítimas de maus tratos. Rev Latino-Am. Enfermagem. 2006;8(1):91-7. doi: 10.1590/S0104-11692000000100013

16. Pasian MS, Faleiros JM, Bazon MR, Lacharité C. Negligência infantil: a modalidade mais recorrente de maus-tratos. Pensando Fam [Internet]. 2013[cited 2019 Jun 26];17(2):61-70. Available from: http://pepsic.bvsalud.org/pdf/penf/v17n2/v17n2a05.pdf

17. Crolman SR. Crianças com síndrome de Down e problemas de comportamento: estilos e práticas educativas de seus genitores. Juiz de Fora. [Dissertação] [Internet]. Universidade Federal de Juiz de Fora; 2018[cited 2019 Jun 26]. Available from: https://repositorio.ufjf.br/jspui/ handle/ufjf/7152

18. Bringiotti MI. La escuela ante los niños maltratados. Buenos Aires: Paidós Iberica; 2000. 246 p.

19. Eichherr LM, Cruz LR. Violência contra crianças e adolescentes: (in)visibilidades e problematizações. PSI UNISC. 2017;1 (1):74-87. doi: 10.17058/psiunisc.v1i1.9804

20. Santana RP, Santana JSS. Violência contra criança e adolescente na percepção dos profissionais de saúde. Rev Enferm UERJ. 2016;24(4):e7070:1-6. doi: 10.12957/reuerj.2016.7070

21. Conselho Regional de Enfermagem. COREN-RJ. Código de ética de enfermagem [Internet]. 2017[cited 2019 Jun 20]. Available from: http:// www.coren-rj.org.br/wp-content/uploads/2017/08/OH-067-16-LIVRO-CODIGO-DE-ETICA-COREN-RJ-FINAL.pdf

22. Nogueira JWS, Rodrigues MCS. Effective communication in teamwork in health: a challenge for Patient Safety. Cogitare Enferm. 2015;20(3):636-40. doi:10.5380/ce.v20i3.40016

23. Thomazine AM, Oliveira BRG, Viera CS. Atenção a crianças e adolescentes vítimas de violência intrafamiliar por enfermeiros em serviços de pronto-atendimento. Rev Eletrôn Enferm. 2009;11(4):830-40. doi: 10.5216/ree.v11i4.33237

24. Klippel YAM, Camargo D. Processo participativo entre profissionais de saúde para integrar o atendimento à criança vítima de violência. Pesqui Prát Psicossociais [Internet]. 2015 [cited 2020 May 19];10(2):340-53. Available from: http://pepsic.bvsalud.org/pdf/ppp/v10n2/11.pdf 